REVERSE MIGRATION: BLESSING IN DISGUISE FOR THE DEVELOPING STATES

\author{
Dr. PAVNESH KUMAR ${ }^{1}$ \& RAUSHAN KUMAR ${ }^{2}$ \\ ${ }^{1}$ Professor, School of Commerce \& Management Sciences, Mahatma Gandhi Central University, Bihar, India \\ ${ }^{2}$ Research Scholar, Dept. of Management Sciences, MGCU Bihar, India
}

\begin{abstract}
The COVID 19 Pandemic has hit across all the corners of the country. COVID 19 had destroyed economies, homes; availability of food and has created the mass exodus of migrant workers due to the Shutdown of the market. The Reverse Migration will perhaps create the greatest crisis in Metro Cities due to an acute shortage of manpower and it will create a sudden demand for employment in our rural India and our Rural India is not yet prepared for such a huge and sudden migration that taking place from the cities. But Reverse migration has also brought a hope for developing states like UP, Bihar, Bengal, Rajasthan, and many more. There are more opportunities in rural economy rather than just agro and farming activities. This paper aims at reviewing the role of Reverse migration in the revival of the economic conditions of underdeveloped and developing states along with the country by providing them with a proper working environment. We need to turn COVID Crisis of reverse migration into opportunity. To support the rural economy, the government should make proper agricultural and industrial policies to stop "footloose" (hired people from rural areas to urban). To overcome these problems Hon'ble PM of India ShriNarendraModiJi has come up with "AatmaNirbhar Bharat Abhiyan" that promotes local product and economy. The paper also briefs about the challenges coming from Reverse migration as there are many challenges like less Social resources, technological resources, and infrastructure, etc. The Paper concludes on how Reverse migration can contribute to the growth of the developing states along with the country and minimizing the rate of unemployment and make India self-dependent (AatmaNirbhar).
\end{abstract}

KEYWORDS:- COVID 19, Reverse Migration, Economies, Self-dependent (AatmaNirbhar)

JEL Classification:- J08, J21, J46, M54

Received: Jun 06, 2020; Accepted: Jun 26, 2020; Published: Jul 16, 2020; Paper Id.: IJMPERDJUN2020344

\title{
INTRODUCTION
}

Covid 19 has been destroying almost all economies of the world. The pandemic devastated almost all incomes of the people but migrants workers are mostly affected in every corner of the country. Migrant workers are known as an engine of the economic growth of any country. But due to lockdown migration of migrants workers will have a significant impact of their own livelihood and economy of a country. Migrants are generally moved from rural to urban areas in search of Job and livelihood. But the Mass migrations of semi skilled and unskilled labors are due to rapid urbanization and globalization. As we see the more the economic growth, the more the mass migration. According to Census of India most of the female workers are mentioned 'Marriage' as the reason for migration whereas for Male, employment and education are the major reason for migration (Office of the Registrar General \& Census Commissioner 2001). Generally migration changes the shape of the cities, but mass migration refers to large number of people from a particular geographical area that leads to serious regional imbalance between the states. According to the Ministry of Housing report,urban to urban migrants are regularly increasing per 
decade,in2011, urban to urban migrants has risen from $15.6 \%$ to $22.6 \%$ (Ministry of Housing and Urban Poverty Alleviation. 2017). Due to lack of political and economical policies migrants is a serious issue.Many programmes and policies were made but they do not reach to them due to corruption and political unwillingness.

However sudden pandemic of Covid results to reverse migration and it will remind us to there is need of urgency about self dependent (AatmaNirbhar). Every state of India should be self dependent so that mass migration could stop. This research paper presents how reverse migration could be helpful in designing a new infrastructure of work environment in Rural India. The current study also offers insights on the impact of reverse migration on developing states.

\section{Causes of Migration}

There are many causes of migration, some are voluntarily and some are involuntarily. There is pull and push factors working on migration. As developing states pushing their citizen to live with slum life in Cities and developed states are acting as pulling the cheap workers from villages. There is need for proper policies framework to make regional balance. Millions of workers are migrated from UP, Bihar, Rajasthan, MP to the big cities like Maharashtra, Delhi and Kolkata for the promise of better standard of living.

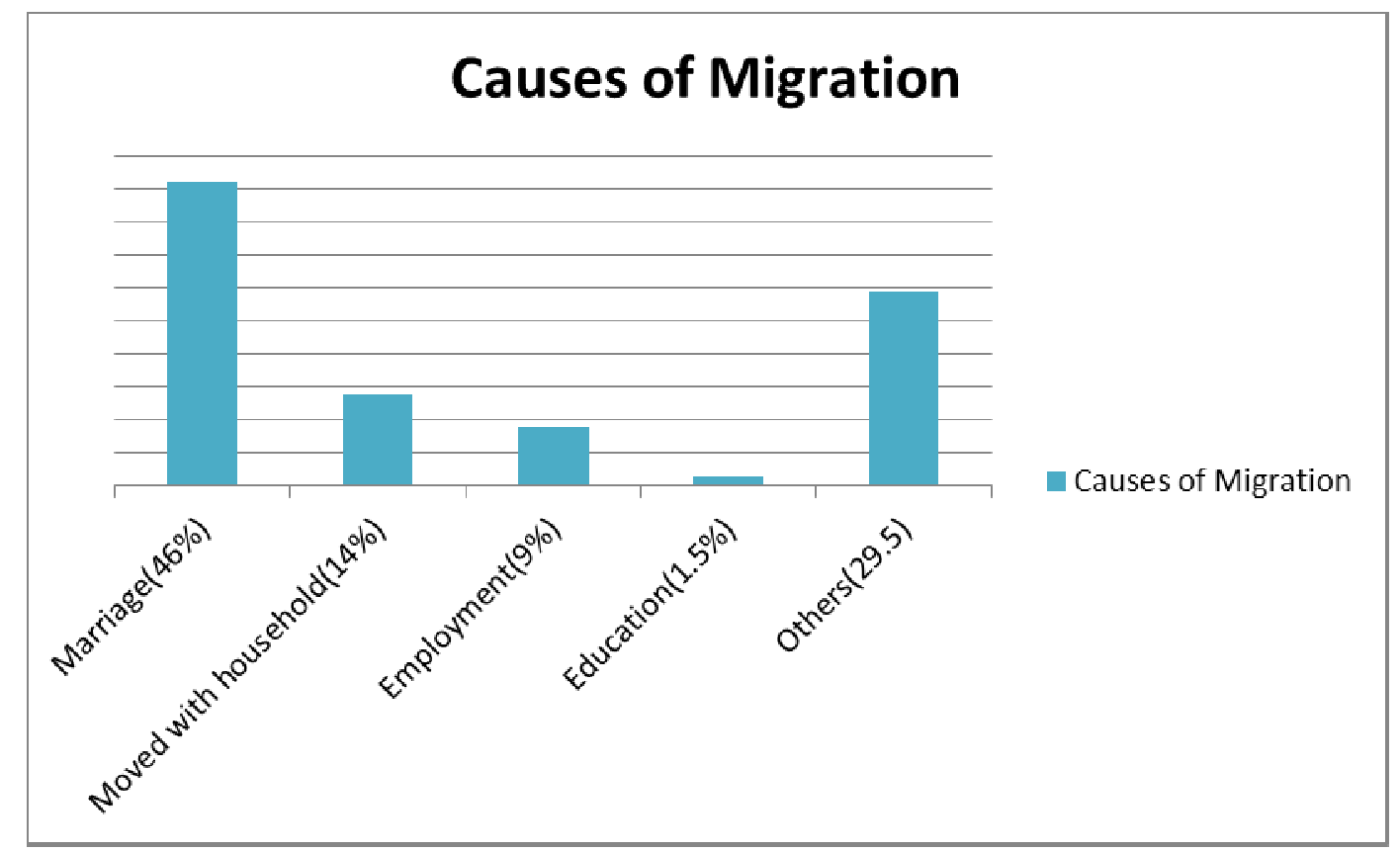

Source: Census of India, 2011 (Census of India 2011)

According to the census 2011, marriage is the main reason for migration in women and employment and education accounts only $11 \%$. Due to poor economic conditions of the family people are migrated to urban areas. Some people may be migrated to get rid of debt. So, migration have helped them to get rid of debt. Due to migration migrants have some good monetary conditions but they are lagging behind psychological peace.

\section{Reverse Migration due to Covid-19}

Due to Pandemic large no. of migrants are migrated from urban to rural areas, this is called Reverse migration. Due to migration, migrants not only lose their livelihood but also they may be carrier of the infectious disease. Migrants have no any formal access to food, shelter, Clothes and even govt. benefits because due to informal livelihood they don't have 
ration card. The reverse migration will going to affect both the places like native and earning places because native place of migrants workers has lack of infrastructure and economic activity (Gupta 2020). So, these reverse migrations willgo to put pressure on developing states too.Due to Nationwide lockdown since March, migrants livelihood are now affecting in all aspects due to breakdown of market and economic activities. According to Ministry of Home affairs India there are almost 4 crore migrants worker in India and almost more than 70 lakhs migrants workers are now back to home (The Times of India 2020). Due to psychological difficulties, migrants workers will not again returned back in cities soon and they will going to explore livelihood in native places. But the problem is that there is less to no economic activities available in developing states like UP and Bihar. So State govt. has big challenge for revival of the old or indigenous industries or to attract more economic activities from Metro cities. Reverse migration will also going to impact on metro cities due to shortage of labours and available workforce. Due to reverse migration India's urban economy has been badly affected than rural economy. Various industries like Hotel and Hospitability, Cinemas, Tourism has earned zero revenue in this period due to completely shutdown. With no infrastructure, no medical facilities, poor communication, developing states could be inviting reverse migration and this will also lead to community transmission of Corona Virus.

\section{OBJECTIVES OF THE STUDY}

- To find the opportunities of livelihood in developing states.

- To find the impact of reverse migration in rural India.

- To find the issues and challenges coming from reverse migration in rural and developing states.

- To find the economic package and benefits and responses from various govt.

\section{RESEARCH METHODOLOGY}

This Research Paper has been based on secondary data source. The data is collected through different authentic sources, websites and research paper from various journals. The data has been collected and analyzed in a standardized way. The Research paper is basically based on exploratory to define the nature of problem. This Paper is based on qualitative in nature.

\section{Issues and Challenges in Reverse Migration}

According to the Ministry of Home affairs, India, approx 4 crore migrant workers in India.Bihar, UP, Madhya Pradesh and Rajasthan accounted for 50\% India's total interstate migration(Kawoosa 2019). As we see Hindi Belt states are accounted more migrants than any other. These migrations create regional disparities among the states. Maharashtra and Delhi accounted highest migration from the rural states of India. That means the state which is poorer;receive the low level of migration, i.e. there is negative relationship between poverty and migration.

There are many issues and challenges arising in reverse migration:-

- Poor infrastructure:-Developing states like Bihar, UP, Madhya Pradesh and more are lagging behind in socio economic conditions. They have no any proper infrastructure to attract industrial investment. These states mainly depend on agriculture but the situation of agriculture is also not so good. Like they are lagging behind cold storage, food processing unit, co-operative societies etc. Many districts of UP and Bihar has also no formal access of roads. 
- Poor Agriculture Policy:-Indian agriculture sector employs nearly half of the workforce and it contributes nearly $17 \%$ of the overall GDP and this GDP regularly decreasing, like agriculture contributes more than 50\% of GDP after Independence (PRS INDIA 2016). Due to poor agricultural policy Indian states are lagging for good agricultural infrastructure. Land holding size of agriculture due to rapid modernization is also one of the reasons behind this. Despite poor infrastructure UP and Bihar is top contributor in Sugar and Jute. So these states need committed policies to create economic activities.

- High density: -Some Developing states have highest density population but lowest literacy rate. According to the Census 2011, Bihar is the highest density state, West Bengal is at $2^{\text {nd }}$ and UP at $4^{\text {th }}$ in India (Census of India 2011). But the problem is the workforce available in these states is migrated from their native place in search of livelihood. We are not utilizing the good human resources of these states. So due to poverty, no good educational policy, low skilled, poor governance etc resulting to low industrial investment.

- To Provide basic support of Income and Health:-Due to mass migration, developing states will going to face huge crisis of management policy. To provide basic income facilities to the workers is the main challenge because govt. is not ready to provide instantly jobs to the migrants. Most of the migrants workers are not registered in govt. formal benefit services. So identify them and provide them is the major challenge for govt. in upcoming days. Healthcare facilities of Delhi and Mumbai are totally breakdown due to Covid, so can you believe if there will be infection spread then health care facilities will also going to be collapsing. So Proper check the migrants and provide him psychological support is much needed.

\section{GOVERNMENT ASSISTANCE FOR REVERSE MIGRATION}

After continuous lockdown, migrant workers have lose job, livelihood, food and shelter. Through internal and international movement, states like UP and Bihar will be more sufferer state. Whatever any government has announced, it is for registered people but the many migrant workers are unregistered and they don't have proper identity card to prove. Central govt. is now starting mapping migrant workers. The migrant workers have been hardest affect due to economic impact of lockdown. There are some assistance provided by government are as follow:-

- Mapping of Migrant workers:-To create database of migrant workers is really a challenging task because they're in informal manner, they don't have ration card and bank account. Mapping of migrant workers will also help the govt. to arrange the transportation and relief camp facilities. According to some statement approx 5 lakh migrant workers had to walk by foot for his journey due to unavailability of transport services (Jha 2020). Mapping of organized labor's with the help of Aadhar Card is sometime very much possible but mapping of unorganized migrant workers is really a difficult for govt. The database will ascertain whether the migrant workers have formal bank account and Aadhar Card then they will get benefit under 'PradhanmantriUjjwalaYojna' and 'Pradhanmantri Jan DhanYojna'.

- AatmaNirbhar Bharat Package:-The central government hadannounced package of 21 lakh crore that was announced by Finance minister Smt. NirmalaSitharaman. This is a big and first ever good amount of economic package announced by any govt. Central government also planning for free food grains for 8 crore migrants, This will total cost of 3100 crore.

- $\quad$ Free Food grain to all:- Central government had also announced the free food grains to all migrant workers, this will also include those workers who were neither beneficiaries under Food and Security act (NFSA).This will total 
cost of 3500 crore. It will offer free $5 / \mathrm{kg}$ free food grain in a month for two consecutive months (Hindustan Times 2020).

- One Nation- One Ration:- Due to many unregistered workers, and don't have proper identity proof, which can specify their work status. Government is now think about one nation one ration card policy but it will take some months. With availability of such unique card will be beneficial for migrant workers and government too in the period of crisis. This time there must be need of single portable card for migrant workers (Kumar 2020).

Despite of that several state government also implementing policies and programmes at their local level. But some state is seems to be failed to helped migrant workers. Many state government like West Bengal were no permitting of shramik express in their states claims Indian Railway. Due to poor communication between the states and center, migrant workers are now sufferer.

\section{SUGGESTIONS}

- Agrarian Economy:- Since Bihar and UP are lagging behind in many parameters but these developing states have better natural resources and agro-climatic conditions. But the main problem is to no proper policies implementation in agrarian economy. The both states are situated in the gangetic plains and alluvial soil. Only $50 \%$ of agricultural land in Bihar is irrigated and only $60 \%$ in UP(Sharma 2014).

- Inclusive Growth:- For faster Inclusive growth, we need a good infrastructure in globalised world (Planning Commission (Government of India) 2008). Good infrastructure includes in overall development like roadways, railways, electricity, water facility and all. If we don't provide better infrastructure or environment for workers then we can't connect with our ruralareas and this led to failed in our inclusive growth. So there is a positive relationship between good infrastructure and inclusive growth.

- Revival of shunted industries:- Many developing states like Bihar, Bengal and UP has large no of shunted industries but due to political rivalry and instability these mills, factories and workshops are closed. Those Migrant workers who returned to home after walking several days are now seek revival of industries and factories in Bihar. For a temporary course of action govt. should be focusing in food processing units and co-operative dairy unit. Many industries in Bihar like Fox nut (Makhana), Handloom and Art industries should be revived. Bihar deputy CM Shri Sushil Kumar Modi said "Bihar produces around $80 \%$ of the Makhana (Fox nut) in the world “. So it needs global promotion of crops (The Times of India 2020).

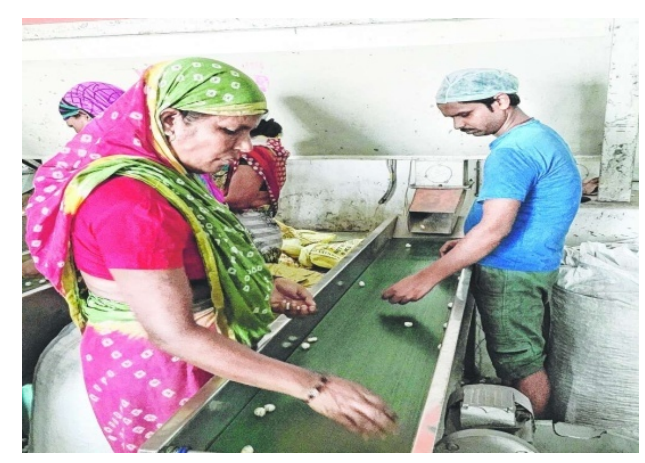

Fox nut (Makhana) industries, Source:- https://www.telegraphindia.com/

- PPP Model:-There is need for strong commitment of Public and Private partnership in Industries. Mainly rural road, electricity, sanitation and infrastructure development needed for economic environment. Attracting private 
investment may be challenging for the developing states but state govt. should started the initiative and provide good environment to the private investors. As we see in railway many services like sanitation and redevelopment of stations are done under PPP model, this provides quality of service to the passengers.

- Decentralizing the services:- Due to reverse migration not only central govt. but state govt. should too decentralizing the various schemes and policies. There is a need of local govt. to provide protect and promote the migrants. And apart from decentralization, state need to converge various programmes related to livelihood must be made effective for a pandemic period(iips india 2020).

- Vocal for Local:- Prime minister Shri Narendra Modi call for supporting Indian business

- and brands. PM told people not to buy local products but also promote it globally. After the statement many Indian companies like Amul and Parle-G are also call for supporting local products.

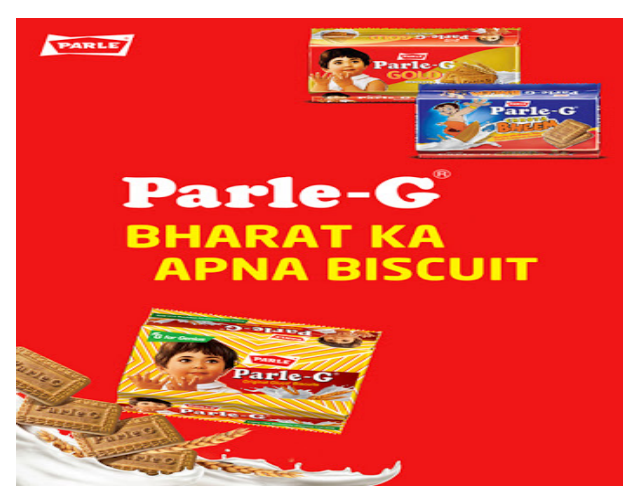

Source:-http://www.parleproducts.com/

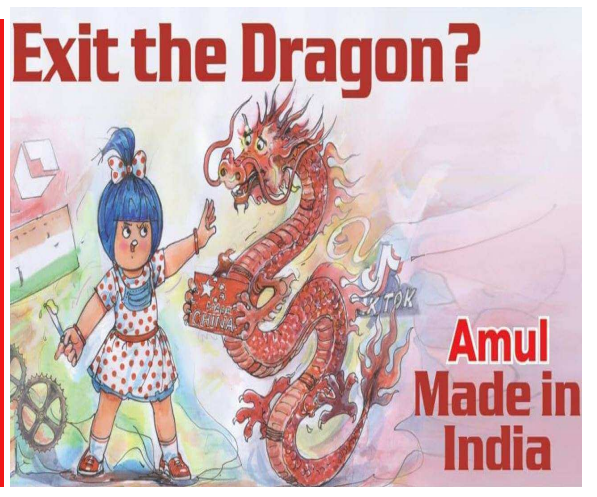

Source:- edtimes.in

Parle-G biscuit advertised its biscuit as "Bharat Ka Apna Biscuit" and AMUL pins twitted "Exit the Dragon(China)".In the time of pandemic only unorganized shops has fulfilled our demand. During the pandemic period local demand and supply chain saves India from hunger, starvation and panic (Mukul 2020). We need a strong environment of home grown business. Due to this pandemic many foreign investors are now planning to invest in India rather than china and this will provide good employment opportunity. This is a golden opportunity for India to export more and less import and make India, a self dependent( AatmaNirbhar) Country.

\section{CONCLUSIONS}

The reverse migration in the context of developing states has emerged after Covid 19. Both causes and consequences of reverse migration in present scenariao of Covid 19 have enormous and in fact overwhelming economic importance for developing states like UP, Bihar, MP, Rajasthan and more. The Present study indicates that there is a big challenge for developing states to manage over workforce coming in their states after Covid 19. Developing states should make a proper action plan to engage their human resources in feasible manner. In short period of time states should collaborate with central govt for providing work to their workforce but in long run states should be Self dependent( AatmaNirbhar) and make a proper policies, programmes and work environment to attract industries, investors and companies in their home state.

However, the findings also revealed that there are such adverse reaction of reverse migration likes to provide basic support and health facilitates in high density states like UP and BIHAR is really a challenging task for state govt and 
it also leads to less workforce in metro cities and this creates regional imbalance. Moreover, migrants have to bear the pain of separation from their children, relatives, friends, social and family ceremonies and it creates more psychological problem due to Covid 19.

\section{REFERENCES}

1. Census of India. 2011. Data on Migration 2011. Office of the Registrar General \& Census Commissioner, India. https://censusindia.gov.in/2011census/d-series/d-3.html.

2. Census of India. 2011. Density of Population. Census of India. https://censusindia.gov.in/2011-provresults/data_files/india/Final_PPT_2011chapter7.pdf.

3. Ezez. 2020. "The COVID-19, Migration and Livelihood in India: Challenges and Strategies". Iipsindia.ac.in. https://iipsindia.ac.in/sites/defaultfiles/iips_covid19_mlli_PB.pdf.

4. Keshri, V R. and S S. Gupta. "COVID, Reverse migration and opportunities to reinvent Gram Swaraj (No." (2020).

5. "Migration." Newdelhi: Office of the Registrar General \& Census Commissioner, India. https://censusindia.gov.in/Census_And_You/migrations.aspx (retrieved June 29, 2020).

6. Planning Commission of India. 2008. Eleventh Five Year Plan. Planning Commission (Government of India). https://niti.gov.in/planningcommission.gov.in/docs/plans/planrel/fiveyr/11th/11_v1/11th_voll.pdf.

7. PRS INDIA. 2016. State of Agriculture in India. NEWDELHI: State of Agriculture in India. https://www.prsindia.org/policy/discussion-papers/state-agriculture-india.

8. Rasul, Golam\& Sharma, Eklabya. 2014. "Understanding the poor economic performance of Bihar and Uttar Pradesh, India: a macro-perspective". Regional Studies, Regional Science 1 (1): 221-239. Informa UK Limited. doi:10.1080/21681376.2014.943804. https://rsa.tandfonline.com/doi/pdf/10.1080/21681376.2014.943804.

9. "REPORT OF THE WORKING GROUP ON MIGRATION." Ministry of Housing and Urban Poverty Alleviation. http://mohua.gov.in/upload/uploadfiles/files/1566.pdf (retrieved June 29, 2020).

10. Ezez. 2020. "Bihar: Local industries gear up to explore global market | Patna News - Times of India". The Times of India. https://timesofindia.indiatimes.com/city/patna/local-industries-gear-up-to-explore-global-market/articleshow/75781374.cms.

11. Ezez. 2020. "Cabinet approves Rs 3,110 crorefoodgrain package under AatmaNirbhar Bharat package, 8 crore migrants to benefit". Hindustan Times. https://www.hindustantimes.com/india-news/cabinet-approves-rs-3-110-crore-foodgrain-packageunder-aatma-nirbhar-bharat-package-8-crore-migrants-to-benefit/story-IGnFqGIAzeA7jHw9nAZvKO.html.

12. https://timesofindia.indiatimes.com/india/4-crore-migrant-workers-in-india-75-lakh-return-home-so-farmha/articleshow/75927222.cms (retrieved June 29, 2020).

13. jha, Abhishek. 2019. "What the 2011 census data on migration tells us". Hindustan Times. https://www.hindustantimes.com/delhi-news/migration-from-up-bihar-disproportionately-high/storyK3WAio8TrrvBhd22VbAPLN.html\#: : text=1., migrants\%20according\%20to\%20that\%20enumeration.

14. Jha, Somesh. 2020. "Covid-19 impact: Govt begins mapping of migrant workers for relief measures". Business-standard.com. https://www.business-standard.com/article/economy-policy/coronavirus-lockdown-govt-mapping-migrant-workers-for-reliefmeasures-120040901787_1.html.

15. Chaudhary, R. A. S. H. M. I., et al. "Factors Limiting rural Youth Participation in agriculture based Livelihood activities in Tehsil Karsog of Himachal Pradesh, India." International Journal of Agriculture Science and Research 8.3 (2018): 141-146. 
16. Kumar, Sanjay. 2020. "What government agencies can do to ensure safety and security of migrant workers". Times of India Blog. $\quad$ https://timesofindia.indiatimes.com/blogs/toi-edit-page/what-government-agencies-can-do-to-ensure-safety-andsecurity-of-migrant-workers/

17. Mukul, Pranav. 2020. "Brands, local and global, get vocal about their Indian roots". The Indian Express. https://indianexpress.com/article/cities/delhi/brands-local-and-global-get-vocal-about-their-indian-roots-6425762/.

18. MEHER, GURUDEV. "RETHINKING ENGLISHNESS: MULTICULTURALISM AND THE QUESTION OF BELONGING." International Journal of English and Literature (IJEL) 7. 2, Apr 2017, 85- 94

19. Bangar, Ashwini, and SwapnilShinde. "Study and comparison of cryptographic methods for cloud security." Int J ComputSciEngInfTechnol Res 4.2 (2014): 205-213. 